Acta Theriologica 37 (1 - 2): 171 - 179, 1992.

PL ISSN $0001-7051$

BISONIANA 107

\title{
Microscopic structure of the thyroid gland in the European bison
}

\author{
Bogusław SAWICKI, Stanisława SIUDA and Irena KASACKA
}

Sawicki B., Siuda S. and Kasacka I. 1992. Microscopic structure of the thyroid gland in the European bison. Acta theriol. 37: 171 - 179.

The thyroids of 85 European bison, Bison bonasus (Linnaeus, 1758) collected from the selectively shot animals ( 43 males and 42 females) in the years $1982-1984$ in the Białowieża and Borecka Forests, were examined. The animals were shot in winter at low temperatures: (Dec., and Jan. - March) as well as summer (June Sept.). Their age ranged from 1 month to 25 years. The thyroid of calves shoved small differentiation in histological structure. Size of the follicles as well variability of their shape increases significantly in older animals, and large follicles are present in relatively great number in the very old bison. Characteristic histological signs of higher activity of the thyroid can be noticed in warm summer months as compared with low temperature winter months.

Department of Histology and Embryology, Medical Academy, Kilińskiego 1, 15-230 Białystok, Poland

Key words: Bison bonasus, thyroid histology

\section{Introduction}

Differences in the histological structure of the thyroid gland in relation to animal's age, reproductive cycles and such physiological factors as pregnancy, feeding and others have been described in many wild animals. In mammals of the Bovidae family such investigations have only been carried out in stock animals: cattle (Arnold 1916), asiatic water buffalo Bubalus bubalis (Mathur 1917), Indian buffalo Bos bubalis (Roy 1971, Roy and Yadava 1974), Egyptian buffalo and cattle (Shafie and Mashaly 1974). Considering the lack of such research on wild representatives of the Bovidae, we decided to present histological structure of the thyroid in European bison, the species being still included in the list of animals threatened with extinction.

\section{Material and methods}

The histological structure of the thyroid gland was examined in 85 European bison, Bison bonasus (Linnaeus, 1758), which ranged in age from 1 month to 25 years (Table 1). The age of the animals 
Table 1. Age, sex, and number of the European bison shot in various months which were examined.

\begin{tabular}{llcccccccr}
\hline \multirow{2}{*}{ Age class } & Sex & Jan. & Febr. & Mar. & Apr. & June & Sept. & Dec. & Total \\
\hline Calves (> 1 year old) & Males & 2 & 4 & 3 & 1 & 0 & 0 & 7 & 17 \\
& Females & 4 & 5 & 4 & 0 & 1 & 0 & 4 & 18 \\
Juveniles (1-4 years old) & Males & 1 & 2 & 4 & 1 & 0 & 2 & 0 & 10 \\
& Females & 3 & 0 & 2 & 2 & 0 & 2 & 0 & 9 \\
Adults (4 years old) & Males & 3 & 4 & 3 & 1 & 2 & 1 & 2 & 16 \\
& Females & 3 & 3 & 2 & 3 & 1 & 3 & 0 & 15 \\
\hline
\end{tabular}

examined was established according to a sequence of teeth erruption and a degree of teeth wear (Węgrzyn and Serwatka 1984). The animals, all free-ranging, were selectively shot in the years 1982 - 1984 in the Białowieża and Borecka Forests. Three samples were collected from the medial part of the left thyroid lobe of each animals and fixed in Bouin's fluid. Parafin sections $(7 \mu \mathrm{m})$ were stained with $\mathrm{H}+\mathrm{E}$ by the Azan and Grimelius methods as modified by Sawicki and Bajko (1974).

\section{Results}

The thyroid gland in bison consists of 2 lobes joined by a relatively narrow and short glandular isthmus. It shows a significant individual variability of size and shape of particular lobes as well as other parameters (S. Serwatka, in prep.).

Bison thyroid frequently exhibits "atypical follicles" of ultimobranchial origin which have different microscopic structure. They can be found in the areas of the gland with increased amount of connective tissue separating the follicles. Their epithelial lining exhibits heteromorphism. In the same follicle different types of epithelium can be seen, from the monolayer type to the multirowed or even multistratified ones. Such atypical follicles are usually filled with different content. Most often it is a very light colloid, visibly foamy at times, with frequent addition of other structures. Most frequently in typical preserved ultimobranchial bodies a significant number of follicles are filled with the fine-grained content, being very difficult to identify. Relatively often, in the follicles of ultimobranchial origin desquamatec epithelial cells, sometimes in great amount, or so-called "cellular debris", being the result of their break-down, are observed. In some of the animals "preserved ultimobranchial bodies" occur (Fig. 1), which have structures analogous to that of the lower vertebrates where they act as an independent endocrine gland (see Sawicki 1991). The rest of the thyroid has a typical mammalian histological structure. No sex-related differences were found in its histological structure. At the same time age dependent differences (Fig. 2 and 3) and seasonal variations were observed. 
In all the bison examined the thyroid follicles varied greatly in size and shape. Their polymorphism increases significantly with advancing age of the animals and is the most visible in the very old (especially in those over 20 years of age), where infrequent, unusually large follicles reaching $1000 \mu \mathrm{m}$ (the size of the biggest section diameter, Fig. 4) are found. Such large follicles are encountered in very old animals even in deeper layers of the gland while in calves the largest follicles can be observed in the outer layer of the organ. The calf thyroid consists of small follicles whose diameter seldom exceeds $150 \mu \mathrm{m}$. The shape of these follicles is more rounded than that of older animals (Fig 2 and 3). The follicles in the calf thyroid are filled with very liquid colloid. The epithelium of these follicles was predominately tall cuboidal, and some areas of columnar epithelium were occasionally seen (Fig. 5). In the thyroid of very old animals the epithelium is low cuboidal, becoming visibly flat in larger follicles (Fig. 4). These follicles contain dense colloid.

Described differences in the structure of the thyroid related to the animal's age coincide with seasonal changes. This variation also increases with advancing age. In summer (June) and in early autumn (September) the thyroid follicles are lined with distinctly higher epithelium than in low temperature winter months (including April). This tendency occurs in all age groups examined. In this period columnar epithelium can be found in calves even in bigger follicles, especially in the region of specific indentations into their interior (Fig. 6). Most follicles contain very thin colloid at that time. The thyroid in calves even in winter is dominated by the cuboidal epithelium and flattened epithelial cells are seen only sporadically in larger follicles. In young and adult animals seasonal changes tend to be more distinct. Their epithelium is significantly higher in warm months of the year compared with winter time (Fig. 7). Moreover, even in very old animals with unusually big follicles, areas of the thyroid gland with thin foamy colloid and high cuboidal epithelim can be seen in the summer period. At the same time various height of the epithelial lining can be often observed in the same follicles (Fig. 8). In winter months (including April) the thyroid of young and adult animals consists primarily of low cuboidal epithelium along with a distinct number of higher density, dark stained by the Azan method. Big and very big follicles are visibly lined with flat epithelium composed of dark cells with "pyknotic" nuclei. In winter, follicles of this type are especially numerous in very old animals (Fig. 4).

In very young calves ( 1 month old in particular) areas of the thyroid with numerous groups of interfollicular cells are observed - some of them being impregnated with silver salts and recognized as $\mathrm{C}$ cells. Formation processes of new small follicles as well as more numerous cell divisions than in the adult thyroid can be seen among interfollicular cells.

C cells (calcitonin-forming) in the bison thyroid occur most frequently in a typical parafollicular position, alone or in small groups. Sometimes they form bigger groups among interfollicular cells. 


\section{Discussion}

The thyroid plays an important role in the process of mammalian adaptation to changing environmental conditions. Its secreted hormones, thyroxin $\left(\mathrm{T}_{4}\right)$ and triiodothyronine $\left(\mathrm{T}_{3}\right)$, are necessary for normal growth and development. The significance of these hormones in the process of thermoregulation is commonly known. They stimulate oxidative phosphorylation in the mitochondria of cells, increasing oxygen consumption and heat production (Orłowski 1989). The thyroid is also an important link in the regulation of calcium and phosphate balance changes due to calcitonin secreted by $\mathrm{C}$ cells.

It has been known for several decades that the microscopic structure of the thyroid reflects its functional state. Many investigations were carried out on the thyroid of domestic, laboratory and wild mammals, taking into account different morphological parameters. Some years later their usefulness was proved when compared with radioisotopic tests and measurements of the thyroid hormone levels in the serum (Zimmermann and Emrich 1970, Robiller et al. 1972, Seffner 1980). Also electron microscopic investigations confirmed the existence of distinct functional phases of the follicular epithelium comparable with the images seen under the light mirroscope (Blähser and Schnorr 1971).

Three basic processes taking place in the thyroid determine its histological structure: synthesis of hormones, storage and their reversible resorption. The so-called "phase of relative balance" is an indirect state between the synthesis and resorption processes on the one hand, and hormone storage on the other. Cuboidal thyreocytes and the decided prevalance of middle size follicles seem to be morphological expressions of this state.

The increased activity of thyreocytes may result both from the intensive hormones synthesis (secretion phase) and their intensified resorption from the colloidal follicles (resorption phase). This resorption is induced by TSH. In this phase thyreocytes are high, their round bright nuclei are situated at the base of the cells while in the top parts - under intensive resorption - small drops of the absorbed colloid appear. Although marginal vacuolization of the colloid observed in this period is the artifact - being the result of fixation, the colloid rarefaction, due to resorption, promotes its formation. When the secretion processes prevail, thyreocytes are also high and polarized. Their bright, big and rounded nucleus lies higher and more to the centre of the cell, and Golgi apparatus is placed under the nucleus on the side of vessels. When the storage processes dominate in the thyroid (storage phase), an increase in the follicles, "expanded" by the condensed colloid, can be observed. These follicles are lined with low, and often distinctly flattened epithelium. In this phase thyreocytes display dark cytoplasm as well as small, dark and sometimes clearly pyknotic nucleus (Blähser and Schnorr 1971, Sawicki and Siuda 1973, Birras 1981).

Pure functional phases of the thyroid, however, occur only in the laboratory. In normal living conditions various phases of the activity can be observed in each 
region of the same thyroid. Our investigations have distinguished two basic seasondependent types of histological structure in the bison's thyroid. In cold months signs of predominance of the colloid storing processes are observed while in warm months a significant increase in the secretion activity and in bigger follicles in the colloid resorption can be seen. The symptoms of resorption mentioned before are especially distinct in old animals, those with predominance of storing processes in winter - the increase in the number of very large follicles with dense colloid and flattened epithelium.

Higher activity in domestic animals in winter compared with summer, being a principle, is interpreted as the stressing influence of winter chills (Gill 1989). Premachandra et al. (1958) found significantly lower contents of $\mathrm{T}_{4}$ in the serum of cattle in summer than in winter or early spring. Shubbur et al. (1989) confirms these observations also in a warmer climate, reporting the highest concentration of $\mathrm{T}_{3}$ and $\mathrm{T}_{4}$ in the serum in winter (December) in the region of France and Iraq in Holstein bulls.

Completely opposite and often contrary results were obtained while examining the thyroid of wild animals. Yousef and Luick (1971) did not find any statistically important differences in $\mathrm{T}_{4}$ level in reindeer Rangifer trandus, despite its living in unusually low temperature. Barth and Horn (1980), however, in roe deer Capreolus capreolus and Bubenik (1978) in stag of white-tailed deer Odocoileus virginianus reported significantly higher $\mathrm{T}_{4}$ values in the serum in summer than in winter.

Varied results of the thyroid activity estimation, dependent on mammal species, were obtained also in histological investigations. It is specific, however, that the animals very well adapted to low temperatures in winter had the thyroid activity defined as low in winter and high in summer. Such observations were reported by Bole and Bavlek (1976) in chamois, Silver et al. (1969) in Virginian whitetailed deer, Sawicki and Siuda (1973) in yellow-necked field mice, Apodemus flavicollis and by Birras (1981) in roe deer. At the same time Birras (1981) noticed morphological signs of the thyroid activity increase in red deer Cervus elaphus in September and October, contrary to roe deer, which she related to the rut period. She described distinct "inactivation of the thyroid" in red deer in winter from November to January. The author connected the reduced activity of the thyroid in winter in these two species with their special preparation to winter conditions.

Morphological signs of storing processes dominating in the thyroid of European bison, observed in our investigations, reflect its low endocrine activity in that period. Gill (1989) also reports the low level of the thyroid hormones in the bison serum in winter. This author refers to his earlier works where he found bison metabolism to be lower in winter than in autumn - before winter comes (cited in Gill 1989). It may be due to special insulating properties of winter fur, sufficient food supply (providing additional food), as well as other processes of adaptation. It is nowadays known that the process of thyroid activity regualtion has very 
complicated links with natural surroundings since through the nervous system it influences "the hypothalamo-pituitary-thyroid axis" (Licht et al. 1990).

Also low day and night activity of European bison in winter observed by CabonRaczyńska et al. (1983), among other things caused by easy access to food, confirms our considerations.

Age-dependent differences in the histological structure of the thyroid, described by us, are more universal in mammals than seasonal changes, and are found both in domestic and wild animals (Mathur 1971, Sawicki and Siuda 1973, Shafie and Mashaly 1974, Roy et al. 1975, Birras 1981).

Smaller sizes of follicles filled with thin colloid and higher epithelial lining than in adults evidence greater endocrine activity of the calf thyroid compared with the adult bison. Lack of visible signs of storage in the thyroid gland in calves in winter period, observed in our investigations, may reflect their much poorer adaptation to winter conditions. The high mortality rate among wild mammals may results, among other things, from the immature hypothalamo-pituitarythyroid axis, i.e. from underdeveloped adaptation mechanisms.

\section{References}

Arnold E. 1916. Histologie der Schilddrüse des Rindes in verschidenen Altersstadien. Arch. wiss. prakt. Tierheilk. 42: $369-391$.

Barth D. and Horn K. 1980. Untersuchungen über das jareszeitliche Verhalten der Blutspiegel von Thyroxin und Harnstoff beim Reh (Capreolus capreolus). Z. Jagwiss. 26: 1- 11.

Birras G. 1981. Histologische und morphometrische Studien an den Schilddrüsen von Rehwild (Capreolus capreolus Linné, 1758) und Rotwild (Cervus elaphus Linné, 1758) unter besonderer Berücksichtigung des Einflusses vor Alter und Jahreszeit. Schriften des Arbeitskreises für Wildbiologie und Jagdwissenschaft an der Justus-Liebieg-Universität Giessen, Ferdinand Enke Verlag, Stuttgar, Heft 7: 1- 139.

Blähser S. and Schnorr B. 1971. Ultrastruktur der Thyreozyten der Ratte im alimentären Tocopherolund Ubichinonmangel und nach Substitution. Z. Zellforsch. 114: 493 - 514.

Bole V. and Bavdek S. 1976. Histometrical determination of the thyroid gland activity of Chamois (Rupicapra rupicapra L.). [In: Tagungsbericht 2. Int. Gamswild-Treffen Blad 1976.

Bubenik G. A. and Bubenik A. B. 1978. Thyroxine levels in male and female white-tailed deer (Odocoilus virginianius). Canad. J. Physiol. Pharmacol. 56: 945 - 949.

Caboń-Raczyńska K., Krasińska M. and Krasiński Z. 1983. Behaviour and daily activity rythm of European bison in winter. Acta theriol. 28: 273 - 299.

Gill J. 1989. Levels of $\mathrm{T}_{4}, \mathrm{~T}_{3}$ and cortisol in the blood serum of the European bison (Bison bonasus) in the winter period. Comp. Biochem. Physiol. 93A: 567 - 569.

Licht P. and Denver R. J. 1990. Regulation of pituitary thyrotropin secretion. Prog. clin. Biol. Res. 342: $427-432$.

Mathur M. L. 1971. Microscopic study of the thyroid gland of the asiatic water buffalo (Bubalus bubalis). Amer. J. vet. Res. 32: $363-366$.

Orłowski W. 1989. Choroby gruczołów wewnętrznego wydzielania. [In: Nauka o chorobach wewnętrznych. W. Hartwig, ed.]. Tom 3, PZWL, Warszawa: $1-502$.

Permachandra B. N., Pipes G. W. and Turner C. W. 1958. Variation in the thyroxin-secretion rate of cattle. J. Dairy Sci. 41: 1609 - 1615. 
Robiller F., Stiller K. J. and Machnik G. 1972. Zeitliche Zusammenhänge zwischen Stoffwechselreaktionen und Epithelzellveränderungen der Schilddrüse. Z. mikrosk. anat. Forsch. 86: $343-348$.

Roy K. S. 1971. Histological and histochemical studies on the thyroid glands of Indian buffalo. M. Sc. (Vet.) thesis. Citation from Roy et al. 1975.

Roy K. S., Saigal R. P., Nanda B. S. and Nagpal S. K. 1975. Gross histomorphological and histochemical changes in the thyroid gland of goot with age. IV, Histomorphological study. Anat. Anz. 143: 86 - 95.

Roy K. S. and Yadava R. C. P. 1973. A note on accessory thyroid tissue in a Indian buffalo. Indian J. Anim. Sci. 43: $344-345$.

Sawicki B. 1991. Ultimobranchial follicles and cysts in the European bison thyroid. Asta theriol. 36: $349-356$.

Sawicki B. and Bajko K. 1974. Introduction of double impregnation in the method of Grimelius. Folia morphol. (Warsz.) 33: 45-51.

Sawicki B. and Siuda S. 1973. Microscopic structure of the thyroid gland in Apodemus flavicollis (Melchior, 1834) over the yearly cycle. Acta theriol. 18: $459-470$.

Seffner W. 1980. Morphokinetik der Schilddrüse des Schweines und die Möglichkeiten der funktionellen Deutung morphologische Befunde. Mh. Vet.-Med. 35: 207 - 209.

Serwatka S. The thyroid gland of the European bison (Bison bonasus). [In prep.]

Shafie M. M. and Mashaly M. M. 1974. Pre- and postnatal thyroid development in bovines. Acta anat. 87: $615-634$.

Shubbur A., Goffaux M. and Thibier M. 1989. Evolution saisonnière des niveaux plasmatiques de thyroxine et de triiodothyronine chez le taureau post-pubère en France et en Irak. Variations concomitantes des taux de LH et de testostèrone. Reprod. Natur. Dev. 29: 309 - 315.

Silver H., Colovos N. F., Holter J. B. and Hayes H. H. 1969. Fasting metabolism of white-tailed deer. J. Wildl. Manage. 33: $490-498$.

Trolldenier H. 1967. Zur Ultrastructur des Schilddrüsenepithels einiger Haustiere (Rind, Schaf and Schwein). Z. mikr.-anat. Forsch. 77: $29-57$.

Yousef M. K. and Luick J. R. 1971. Estimation of thyroxine secretion rate in reindeer (Rangifer tarandus). Comp. Biochem. Physiol. 40: 789 - 795.

Wegrzyn M. and Serwatka S. 1984. Teeth eruption in the European bison. Acta theriol. 29: 111 - 121.

Zimmermann H. D. and Emrich D. 1979. Experimentaller Beitrag zur Frage der Korrelation von Schilddrüsenmorphologie und -function bei der Ratte. Verhandlung der Deutschen Gesellschaft für Pathologie 54. Tagung. Jena, G. Fischer: $367-371$.

Received 20 August 1991, accepted 8 March 1992. 
Plate I

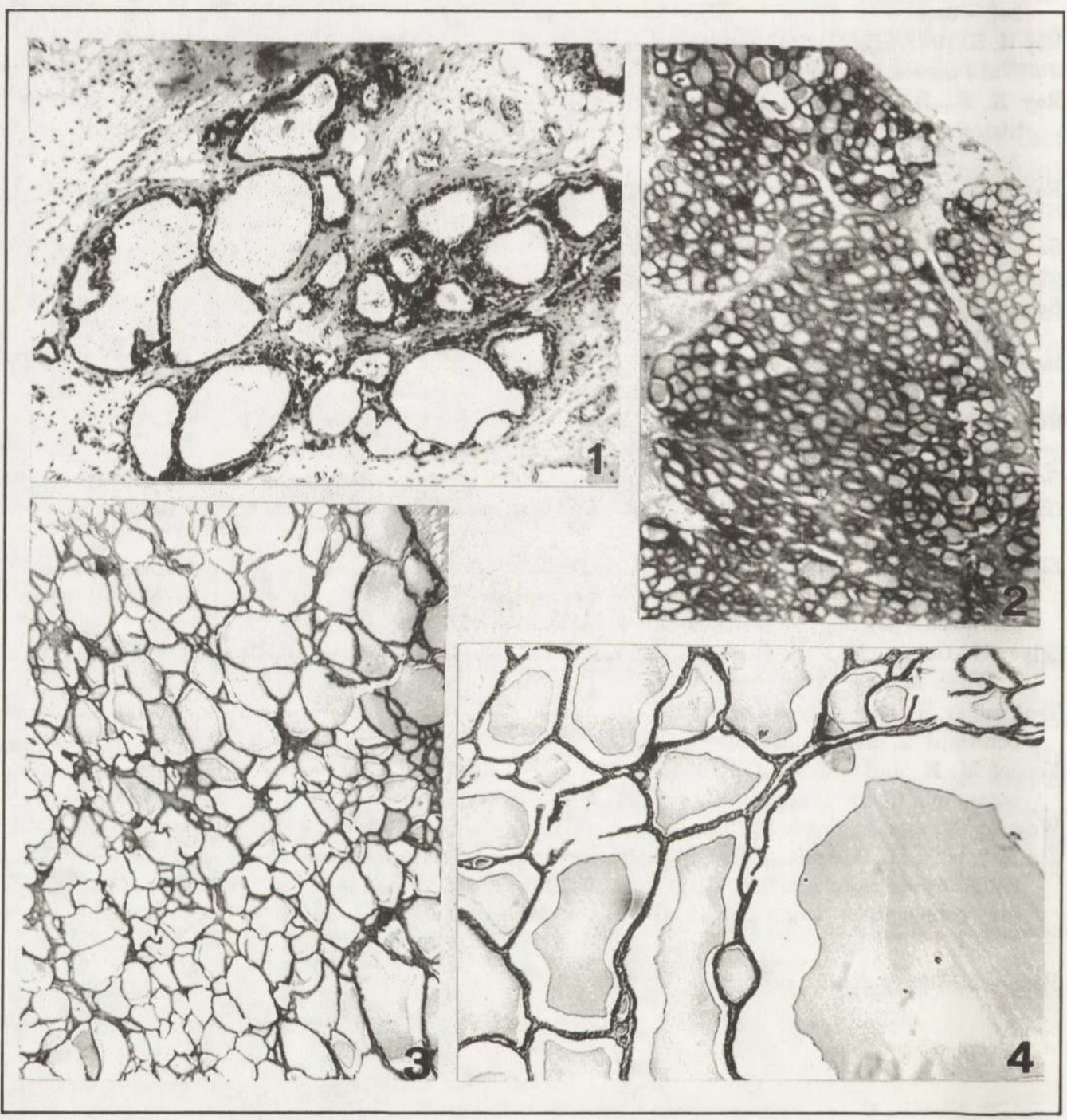

Fig. 1. Ultimobranchial (Ub) body. Follicles of the $\mathrm{Ub}$ body are more loosely positioned in the abundant connective tissue in comparison with follicles of thyroid. The Ub body also presents greater polymorphism of its structures. Female, 3 yrs, autopsy -3 Mar. 1982. H + E. Enl. $\times 80$.

Fig. 2. Thyroid gland. Small and mid-sized follicles are the most numerous. Female, 8 mo., autopsy 16 Mar. 1982. H + E. Enl. $\times 26$.

Fig. 3. Thyroid gland. Larger sizes and more distinct polymorphism of follicles in comparison to young animals are seen (comp. Fig. 2). Male, 10 yrs, autopsy - 28 Apr. 1982. H + E. Enl. $\times 26$.

Fig. 4. Thyroid gland. The epithelium is squamous in large and very large follicles. These follicles contain dense colloid. Female, 21 yrs, autopsy - 17 Jan. 1982. H + E. Enl. $\times 80$. 


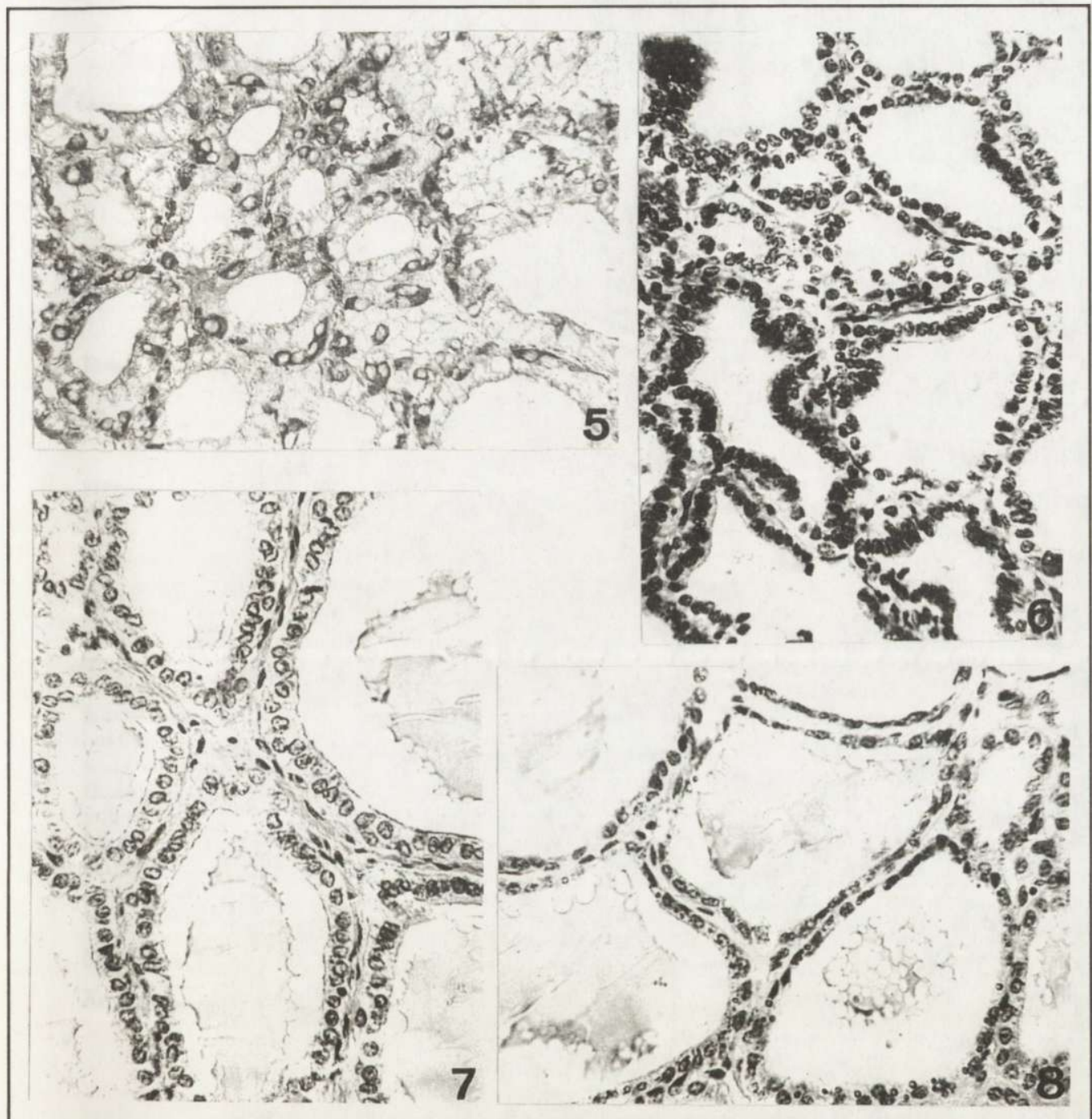

Fig. 5. Thyroid gland. C cells (stained black) are positioned parafollicularly in the thyroid gland. Female, 8 mo., autopsy - 17 Febr. 1982. Gremilius. Enl. $\times 310$.

Fig. 6. Thyroid gland. Columnar epithelium can be found also in bigger follicles, especially in the indentations of their interiors. Those follicles contain very thin colloid. Female, 2 mo., autopsy - 1 Jun. 1982. H + E. Enl. $\times 310$.

Fig. 7. Thyroid gland. Columnar epithelium in mid-sized and large follicles. Male, age 2 yrs, autopsy -27 Sept. 1982. H + E. Enl. $\times 310$.

Fig. 8. Thyroid gland. Follicles of irregular shape are seen; they are lined with epithelium of varying hight. These follicles demonstrate more liquid, foamy colloid. Male, 25 yrs, autopsy - 1 Jun. 1982. H + E. Enl. $\times 310$. 